\title{
Kooperatif Tipe Group Investigation Melalui Setting Lesson Study Terhadap Kompetensi Pengetahuan IPA
}

\author{
*Ni Kadek Rina Widiasari ${ }^{1}$, Made Sumantri $^{2}$ \\ 1,2 Program Studi Pendidikan Guru Sekolah Dasar, FIP, Universitas Pendidikan Ganesha, Singaraja, Indonesia
}

\author{
A R T I C L E I N F O \\ Article history: \\ 1 Maret 2020 Received in \\ revised form \\ 30 Maret 2020 \\ Accepted 11 April 2020 \\ Available online 15 \\ Mei 2020 \\ Kata Kunci: \\ group investigation, lesson \\ study, IPA \\ Keywords: \\ group investigation, lesson \\ study, IPA
}

\begin{abstract}
A B S T R A K
Pengetahuan IPA saat ini masih ada dalam kondisi yang tidak bagus, hal ini disebabkan oleh kurangnya perencanaan yang dilakukan oleh guru, keaktifan siswa belajar, hal itu lah yang mendasari penelitian ini dilakukan. Penelitian ini bertujuan mengetahuai efektivitas pengunaan model group Investigation bersetting lesson study terhadap kompetensi pengetahuan IPA pada siswa SD kelas IV. Jenis penelitian ini adalah penelitian ekperimen semu dengan rancangan penelitian non-equivalent post-test only control group design. Populasi penelitian ini berjumlah 162 siswa. Sampel penelitian ditentukan dengan teknik random sampling, diperoleh kelas IV SDN 1 Penglatan berjumlah 27 siswa sebagai kelompok eksperimen dan kelas IV SDN 3 Penglatan berjumlah 23 siswa sebagai kelompok kontrol. Tes objektif digunakan untuk mengumpulkan data kompetensi pengetahuan IPA kemudian dianalisis menggunakan statistik deskriptif dan statistik inferensial (uji-t).
\end{abstract} Berdasarkan hasil perhitungan dan analisis data, diperoleh rata-rata kompetensi pengetahuan IPA siswa kelompok eksperimen, yakni 17,43 lebih besar dari rata-rata kelompok kontrol, yakni 14,27. Selain itu nilai $t_{\text {hitung }}=2,77>t_{\text {tabel }}=2,01$ untuk signifikansi $5 \%$, sehingga dapat dikatan bahwa penerapan model group investigation berseting lesson study dapat mempengaruhi kompetensi pengetahuan IPA. Dengan adanya model pembelajaran ini akan menjadi alternative guru dalam merancang proses pembelajaran yang lebih inovatif.

\section{A B S T R A C T}

Natural science knowledge is currently still in a bad condition, this is due to the lack of plan that was done by the teacher and the activeness of students' learning, that was the basis of this research. The aim of this research was to determine the effectiveness of the group Investigation model in the set of lesson study toward the natural science competency on fourth grade elementary students. This research was a quasi-experimental with a non-equivalent post-test only control group design. The population of this research was 162 students. The research sample was determined by random sampling technique, there were 27 students of grade 4 elementary students at SD N 1 Penglatan as the experimental group and there were 23 students of grade four elementary students at SDN 3 Penglatan as the control group. Objective tests were used to collect data on natural science competency and then it analyzed by using descriptive statistics and inferential statistics (t-test). Based on the results of data analysis, the average score of experimental group was 17.43 higher than the average score of control group 14.27. In addition, $t$-count $=2.77>t$-table $=2.01$ for a significance level of $5 \%$, so it could be concluded that the application of the group Investigation model in the set of lesson study could affect the natural science competency. This learning model would be an alternative way for the teachers in designing innovative learning processes.

\section{Pendahuluan}

Ilmu Pengetahuan Alam (IPA) tidak terlepas dari disiplin ilmu dan proses ilmiah yang berkaitan dengan fenomena alam sehingga dapat dipelajari, dipahami, dan dijelaskan. IPA bagian dari kegiatan yang mengeksplorasi alam semesta secara prosedural untuk menghasilkan sebuah fakta. Hal tersebut tidak terlepas dari hakikat IPA atau sains yang merupakan proses bagaimana seseorang memperoleh ilmu pengetahuan guna memahami konsep-konsep ilmiah dengan benar melalui berbagai tahapan yang

Copyright (C) Universitas Pendidikan Ganesha. All rights reserved 
sistematis (Tursinawati \& Widodo, 2019). IPA memiliki keterkaitan yang sangat berpengaruh dalam meningkatkan kualitas sumber daya manusia. Keterkaitan tersebut menggunakan IPA sebagai salah satu media untuk mencapai tujuan pendidikan. Sejalan dengan hal tersebut, berarti IPA sangatlah penting untuk dipelajari pada tingkat Sekolah Dasar (SD) sebab membahas tentang peristiwa-peristiwa yang terjadi di alam dan dekat dengan kehidupan siswa (Pindo \& Rinci, 2018). Lebih lanjut, belajar sains merupakan cara ideal untuk memperoleh salah satu kompetensi, yaitu kompetensi pengetahuan IPA. Penguasaan kompetensi pengetahuan IPA dinyatakan sebagai kompetensi pada ranah kognitif yang mampu mengukur tingkat penguasaan atau pencapaian siswa dalam aspek pengetahuan.

Kompetensi pengetahuan IPA termasuk pada kompetensi inti 3. Hal ini senada dengan Permendikbud Nomor 37 Tahun 2018 terkait Kompetensi Inti (KI) dan Kompetensi Dasar (KD) pada kurikulum 2013 yang menyatakan kompetensi inti 3 tentang pengetahuan didasarkan pada sikap keingintahuan siswa mengenai dirinya sendiri, kegiatan mengenai makhluk ciptaan Tuhan, dan sesuatu yang ditemui siswa di lingkungan keluarga, sekolah, serta masyarakat untuk memperoleh sebuah pemahaman secara konsep yang bersifat fakta. Perolehan kompetensi pengetahuan IPA tentunya harus didukung dengan pembelajaran yang ideal. Pembelajaran ideal identik dengan pemberian sebuah rangsangan guna mendorong siswa untuk lebih memahami materi yang dipelajari, itupun tidak lepas dari sifat antusias guru dan siswa. Pembelajaran yang medorong kreativitas siswa secara keseluruhan membuat siswa aktif (student centered) dalam mencapai tujuan pembelajaran yang berlangsung pada kondisi menyenangkan. Pemaparan tersebut sesuai dengan (Hayati, 2017) yang mengungkapkan IPA atau sains merupakan pengetahuan yang diperoleh dengan cara berdiskusi tentang peristiwa yang terjadi di alam mulai pengamatan terhadap benda hidup sampai benda mati. Kegiatan diskusi pada pembelajaran IPA bertujuan untuk menciptakan suasana belajar interaktif dan memberi kesempatan siswa untuk menggali pengetahuan secara mandiri. Sejalan dengan hal tersebut, science atau IPA adalah ilmu yang mempelajari aspek-aspek yang ada di alam baik itu komponen atau interaksi yang terjadi (Samatowa, 2016). Hal yang memberikan pengaruh dalam pembelajaran IPA di SD, yaitu adanya kegiatan diskusi yang berorientasi pada proses penemuan dan pengamatan langsung.

Pembelajaran IPA di SD diarahkan dengan cara mencari tahu tentang alam secara sistematis sehingga IPA bukan hanya merupakan penguasaan kumpulan pengetahuan yang berupa fakta-fakta, konsep-konsep, atau prinsip-prinsip saja, tetapi juga merupakan suatu proses penemuan melalui investigasi kelompok dan pembentukan sikap ilmiah. Mengacu pada hal tersebut, pembelajaran IPA yang ideal hanya mungkin terjadi jika didukung oleh guru yang ideal. Pembelajaran IPA menuntut guru untuk dapat menciptakan pembelajaran yang berorientasi pada partisipasi, keaktifan, dan kerjasama kelompok. Pembelajaran IPA di SD harus menyangkut proses bagaimana kumpulan pengetahuan itu diperoleh agar pengetahuan siswa terhadap materi yang dipelajari dapat diingat dan dipahami dalam jangka waktu yang lama. Pemberian pengalaman secara langsung pada proses pembelajaran IPA memberi peluang siswa untuk memahami, mengeksplor, dan mengembangkan kompetensi pengetahuan sehingga siswa memperoleh sendiri konsep materi yang dipelajari. Pengembangan pengetahuan dasar siswa diperoleh dari bagaimana pembelajaran guru terhadap siswa di sekolah. Proses pembelajaran IPA di sekolah dasar diharapkan mampu menjadi wahana siswa dalam mempelajari alam sekitar dan dirinya sendiri.

Lebih lanjut kegiatan siswa dalam memperoleh pengetahuan IPA dapat dilakukan melalui pengamatan, memprediksi, dan mengidentifikasi materi yang dikerjakan secara berkelompok, dengan demikian setiap kelompok siswa harus terbentuk secara heterogen untuk meningkatkan kompetensi pengetahuan IPA. Beranjak dari pemaparan tersebut, guru semestinya merancang pembelajaran yang bersifat student centered learning. Proses pembelajaran IPA di SD masih dihadapkan pada masalah lemahnya penggunaan model pembelajaran yang kurang tepat sehingga dapat menyebabkan siswa mengalami kebosanan dan kurang termotivasi untuk belajar. Terlebih lagi, kurangnya penerapan model pembinaan profesi pendidik pada perancangan, pelaksanaan, dan refleksi juga menyebabkan proses pembelajaran kurang maksimal. Kenyataan yang ada di lapangan, menunjukkan nilai pengetahuan IPA siswa masih berada di bawah Ketuntasan Belajar Minimal (KBM). Hal ini dialami oleh seluruh siswa kelas IV SD di Gugus IV Kecamatan Buleleng pada tahun pelajaran 2019/2020. Hasil wawancara, pengamatan, dan pencatatan dokumen yang telah dilakukan selama 6 hari dimulai dari tanggal 30 Oktober sampai dengan 5 November 2019 di SD Gugus IV Kecamatan Buleleng, dapat diketahui bahwa hasil Penilaian Tengah Semester (PTS) IPA siswa sebagian besar masih berada di bawah KBM. Secara lebih jelas, hasil PTS IPA siswa kelas IV SD semester ganjil di Gugus IV Kecamatan Buleleng dapat dilihat pada Tabel 1 berikut. 
Tabel 1 Presentase Hasil PTS IPA Siswa Kelas IV SD di Gugus IV Kecamatan Buleleng

\begin{tabular}{clccccc}
\hline No & Nama Sekolah & $\begin{array}{c}\text { Jumlah } \\
\text { Siswa }\end{array}$ & KBM & $\begin{array}{c}\text { Rata-rata } \\
\text { Kelas }\end{array}$ & $\begin{array}{c}\text { Siswa telah } \\
\text { mencapai KBM }\end{array}$ & $\begin{array}{c}\text { Siswa belum } \\
\text { mencapai KBM }\end{array}$ \\
\hline 1 & SDN 1 Penglatan & 27 & 65 & 64,63 & 11 & 16 \\
2 & SDN 2 Penglatan & 29 & 65 & 64,14 & 12 & 17 \\
3 & SDN 3 Penglatan & 23 & 69 & 61,74 & 9 & 14 \\
4 & SDN 1 Alasangker & 35 & 75 & 63,14 & 13 & 22 \\
5 & SDN 2 Alasangker & 36 & 67 & 61,81 & 16 & 20 \\
6 & SDN 3 Alasangker & 12 & 70 & 69,83 & 5 & 7 \\
& Jumlah & 162 & - & - & 66 & 96 \\
\hline \multicolumn{5}{c}{ (Sumber: Wali Kelas IV SD di Gugus IV Kecamatan Buleleng 2019) }
\end{tabular}

Pada tabel di atas, dapat diamati dari jumlah 162 siswa masih terdapat 96 siswa atau sama dengan $59,25 \%$ belum memenuhi kriteria mencapai KBM masing-masing sekolah kisaran 65-75. Ternyata nilai rata-rata siswa kelas IV seluruhnya dari enam sekolah dasar di Gugus IV Kecamatan Buleleng masih berada di bawah KBM. Pada data tersebut dapat dipahami bahwa kompetensi pengetahuan IPA siswa masih berada pada kategori rendah dan perlu ditingkatkan. Berlandaskan pada hasil wawancara dengan guru wali kelas IV di enam sekolah dasar Gugus IV Kecamatan Buleleng diperoleh informasi, yaitu: (1) guru dalam penyusunan perangkat pembelajaran tanpa mengadakan kolaborasi bahkan jarang melaksanakan diskusi dengan guru-guru lain, (2) pada kegiatan belajar berlangsung, guru-guru lain tidak pernah menyaksikan secara langsung proses pembelajaran di kelas (open class) sehingga perilaku siswa tanpa adanya pengawasan, dan (3) pada akhir pembelajaran, guru tidak pernah mengadakan diskusi dengan siswa maupun dengan guru-guru lain. Hal ini mengakibatkan proses pembelajaran jarang dikritisi oleh pendidik lainnya untuk dapat diberikan masukan-masukan terhadap penyusunan sampai dengan pelaksanaan terkait dengan perangkat pembelajaran. Kompetensi pengetahuan IPA siswa kelas IV di sekolah tersebut akan berdampak rendah apabila situasi seperti di atas terjadi secara terus-menerus pada proses pembelajaran.

Berlandaskan hasil pengamatan yang sudah dilaksanakan di kelas IV SD Gugus IV Kecamatan Buleleng selama proses pembelajaran, diketahui bahwa pada proses awal pembelajaran guru jarang melaksanakan apersepsi yang mengaitkan pengetahuan awal siswa. Pada kegiatan inti, siswa hanya dituntut untuk mengerjakan latihan soal pada buku tematik kemudian guru melanjutkan kegiatan ceramah sehingga siswa jarang melakukan interaksi belajar dengan teman sebayanya. Pada kegiatan penutup, guru tidak melaksanakan evaluasi dan refleksi tentang materi yang telah diajarkan. Pembelajaran yang berlangsung kurang kolaboratif sehingga siswa kurang melakukan interaksi dengan teman sebaya selama proses pembelajaran IPA. Pada jenjang SD, perlu ditanamkan akan pentingnya pemahaman IPA siswa. Kesenjangan yang terjadi mengakibatkan kegiatan pembelajaran yang berlangsung belum sepenuhnya mencerminkan pembelajaran ideal sehingga kegiatan lain seperti bereksperimen, partisipasi siswa, dan kerjasama antar kelompok belum terlihat. Terlebih lagi pemberian tugas seperti mengerjakan soal-soal yang hanya terpaku pada buku ajar yang masih bersifat hafalan. Soal pada buku ajar yang hanya terbatas pada hafalan mencakup tingkat mengingat (C1). Tingkat mengingat termasuk dalam tingkatan kognitif yang masih tergolong rendah. Pada kegiatan pencatatan dokumen dan pengamatan diketahui bahwa rendahnya kompetensi pengetahuan IPA siswa di SD dikarenakan cara belajar yang masih bersifat teacher centered learning.

Permasalahan di atas dapat ditawarkan solusi berupa diterapkannya model pembelajaran kooperatif tipe group investigation melalui setting lesson study terhadap kompetensi pengetahuan IPA. Lebih lanjut pentingnya pemilihan model pembelajaran kooperatif tipe group investigation didasari pada keunggulan model dan pengkolaborasian prinsip belajar siswa yang demokratis (Shoimin, 2014). Kondisi ini sejalan dengan apa yang dikemukakan (Santyasa, 2017), bahwa pembelajaran lebih dominan melibatkan siswa aktif atas gagasan-gagasan barunya sebagai langkah awal dalam memperoleh kemajuan hasil belajar. Pembelajaran seperti ini merupakan pembelajaran yang bersifat learning how to learn atau sering juga disebut sebagai pembelajaran inovatif. Pembelajaran inovatif, pada umumnya dikemas oleh siswa secara langsung memposisikan siswa sebagai investigator, activator, dan manager pembelajaran. Mengacu pada hal tersebut, penerapan model pembelajaran kooperatif tipe group investigation memberi keunggulan yang bernuansa pada pembelajaran ideal, yakni: (1) suasana belajar yang menyenangkan saling berinteraksi dan bekerjasama secara heterogen tanpa memandang latar belakang, serta (2) mampu melatih kemampuan siswa dalam berpendapat dan berkomunikasi yang baik (Kurniasih, Iman, \& Seni, 
2016). Prioritas utama model pembelajaran kooperatif tipe group investigation memberi kebebasan siswa bekerja secara interaktif yang bertujuan agar siswa mampu memahami dan menemukan sendiri konsep pembelajaran IPA. Pemahaman siswa diperoleh melalui pengamatan berdasarkan masalah yang dikaji dalam pembelajaran. Selain itu, adapun sintaks model pembelajaran kooperatif tipe group investigation terdiri dari enam tahapan pembelajaran, yaitu grouping, planning, investigation, organizing, presenting, dan evaluating.

Keberhasilan belajar siswa tidak terlepas dari sintaks model pembelajaran group investigation. Sintaks model pembelajaran tersebut menempatkan peran guru sebatas menjadi fasilitator dan narasumber karena secara garis besar pembelajaran student centered learning akan menstimulus kondisi pembelajaran ideal (Shoimin, 2014). Adapun hasil penelitian sebelumnya, (Widiartini, Putra, \& Manuaba, 2019) yang menggunakan model pembelajaran kooperatif tipe group investigation menyimpulkan model pembelajaran tersebut memberi pengaruh yang signifikan terhadap kompetensi pengetahuan IPA. Selain itu, hasil penelitian yang dilakukan (Budiastra, Sudana, \& Arcana, 2015) juga menyimpulkan terdapat pengaruh signifikan keterampilan berpikir kritis siswa pada pembelajaran IPA yang dibelajarkan dengan model pembelajaran kooperatif tipe group investigation. Perbedaan penelitian sebelumnya dengan penelitian ini adalah adanya penerapan lesson study.

Pembelajaran yang di-setting melalui lesson study bertujuan untuk membangun komunitas belajar antar pendidik yang berprinsip kolegalitas. Lesson study adalah model pembinaan profesi pendidik yang dilaksanakan melalui pengkajian pembelajaran secara kolaboratif dan berkelanjutan (Abizar, 2017). Berdasarkan hal tersebut lesson study menganut prinsip kolegalitas antara pengamat dan guru yang selalu bersama-sama dalam melaksanakan pembelajaran. Mengingat pentingnya prinsip kolegalitas dalam mempersiapkan pembelajaran, maka kerjasama antar pendidik sangat diperlukan untuk memperoleh kematangan dan kesiapan guru dalam mengajar (Tristiantari \& Sumantri, 2016). Lesson study diterapkan dengan tahapan yang berkesinambungan dan tidak pernah putus. Tahapan tersebut diantaranya, yaitu tahap plan yang berarti merencanakan, tahap do yang berarti melaksanakan, dan tahap terakhir yaitu tahap see yang artinya merefleksi (Jampel, 2017). Pada tahapan lesson study, guru-guru merencanakan, mengajar, merefleksi bersama-sama dengan guru lain sejenis, dan sering dianggap sebagai research lesson (kaji pembelajaran). Selain itu, peran guru dalam lesson study menemukan dan merancang pembelajaran yang mampu meningkatkan kompetensi pengetahuan IPA siswa. Pernyataan tersebut didukung oleh hasil penelitian sebelumnya yang dilakukan Putra., dkk (2019) menyatakan model pembelajaran kooperatif tipe group investigation berbasis lesson study berpengaruh terhadap penguasaan konsep IPA. Merujuk pada hasil penelitian tersebut, dapat dipahami bahwa penerapan model pembelajaran kooperatif tipe group investigation dan lesson study memberi dampak positif baik bagi siswa maupun bagi guru.

Berlandaskan pada hasil penelitian sebelumnya dan menanggapi permasalahan yang terjadi pada pembelajaran di kelas sehingga dilakukan penelitian dengan judul "Pengaruh Model Pembelajaran Kooperatif Tipe Group Investigation melalui Setting Lesson Study terhadap Kompetensi Pengetahuan IPA siswa SD kelas IV Gugus IV Kecamatan Buleleng Tahun Pelajaran 2019/2020". Tujuan dari pelaksanaan penelitian ini adalah untuk mengetahui perbedaan yang signifikan kompetensi pengetahuan IPA antara kelompok siswa yang dibelajarkan menggunakan model pembelajaran kooperatif tipe group investigation melalui setting lesson study dan kelompok siswa yang dibelajarkan tidak menggunakan model pembelajaran kooperatif tipe group investigation melalui setting lesson study pada siswa SD kelas IV Gugus IV Kecamatan Buleleng Tahun Pelajaran 2019/2020.

\section{Metode}

Jenis penelitian yang digunakan adalah penelitian eksperimen semu dengan rancangan penelitian non-equivalent post-test only control group design. Populasi pada penelitian ini adalah seluruh siswa kelas IV SD di Gugus IV Kecamatan Buleleng yang berjumlah 162 siswa yang terdiri dari 6 sekolah dasar, yaitu SD Negeri 1 Penglatan, SD Negeri 2 Penglatan, SD Negeri 3 Penglatan, SD Negeri 1 Alasangker, SD Negeri 2 Alasangker, dan SD Negeri 3 Alasangker. Uji kesetaraan menggunakan analisis ANAVA satu jalur yang dilakukan terlebih dahulu guna mengetahui apakah kompetensi pengetahuan IPA siswa kelas IV dimasing-masing SD sudah setara atau belum. Berdasarkan pengujian ANAVA satu jalur melalui Penilaian Tengah Semester (PTS) ganjil, kompetensi pengetahuan IPA diketahui bahwa kelas IV SD di Gugus IV Kecamatan Buleleng Tahun Pelajaran 2019/2020 merupakan kelas yang sudah setara karena uji kesetaraan yang diporoleh, yakni $F_{\text {hitung }}=0,58$ lebih kecil dari $F_{\text {tabel }}=2,27$ (taraf signifikan 5\%). Lebih lanjut sampel penelitian ditentukan menggunakan teknik acak (random sampling), yaitu cara mencampur subjek-subjek dalam populasi yang sudah lolos uji kesetaraan sehingga semua subjek dianggap memiliki hak yang sama untuk menjadi anggota sampel (Koyan, 2011). Hasil pengundian secara acak menyatakan siswa kelas IV SDN 1 Penglatan sebagai kelompok eksperimen dan siswa kelas IV SDN 3 Penglatan sebagai 
kelompok kontrol. Perlakuan yang diberikan pada kelompok eksperimen adalah model pembelajaran kooperatif tipe group investigation melalui setting lesson study sedangkan pada kelompok kontrol tanpa diberikan perlakuan model pembelajaran kooperatif tipe group investigation melalui setting lesson study.

Pelaksanaan penelitian ini terdiri dari tiga tahapan yaitu, tahap persiapan, tahap pelaksanaan, dan tahap akhir eksperimen. Pada tahapan persiapan eksperimen, kegiatan yang dilakukan adalah merancang instrumen penelitian berupa perangkat pembelajaran seperti Rencana Pelaksanaan Pembelajaran (RPP), Lembar Kerja Peserta Didi (LKPD), media pembelajaran, tes yang akan digunakan untuk post-test, merancang instrumen penilaian kompetensi pengetahuan IPA, dan mengadakan validitas instrumen penelitian tes kompetensi pengetahuan IPA. Pada tahapan pelaksanaan eksperimen, kegiatan yang dilakukan adalah memberikan perlakuan pada kelompok eksperimen berupa model pembelajaran kooperatif tipe group investigation melalui setting lesson study, sedangkan pada kelompok kontrol berlangsung pembelajaran tanpa diberi perlakuan (pembelajaran rutin yang dilaksanakan secara terus menerus). Sedangkan tahap akhir eksperimen kegiatan yang dilakukan adalah memberikan post-test kepada kelompok eksperimen dan kontrol untuk memperoleh data kompetensi pengetahuan IPA.

Penelitian dilaksanakan kurang lebih selama sepuluh kali pertemuan, yakni pada awal sampai akhir bulan Januari 2020. Penelitian ini melibatkan satu variabel bebas dan satu variabel terikat. Variael bebas pada penelitian ini adalah model pembelajaran kooperatif tipe group investigation melalui setting lesson study sedangkan variabel terikat pada penelitian ini adalah kompetensi pengetahuan IPA. Data kompetensi pengetahuan IPA dikumpulkan melalui metode tes objektif berjumlah 23 butir soal. Setiap soal disertai dengan empat alternatif jawaban yang dipilih siswa, yakni a, b, c, dan d. Setiap item diberikan skor 1 apabila siswa menjawab dengan benar berdasarkan kunci jawaban dan diberi skor 0 untuk siswa yang menjawab salah. Tes yang digunakan sebagai alat ukur untuk mengumpulkan data kompetensi pengetahuan IPA sebelumnya telah dilakukan validasi instrumen yang meliputi uji validitas butir tes, uji reliabilitas tes, uji daya beda, dan uji taraf kesukaran butir tes. Jumlah soal yang diujicobakan adalah 25 butir tes yang sebelumnya sudah dianalisis terlebih dahulu melalui uji validitas isi (uji judges) berdasarkan perhitungan Gregory. Hasil analisis melalui perhitungan Gregory menyatakan tes bersifat relevan (Candiasa, 2011). Selanjutnya dilakukan uji validitas butir melalui rumus korelasi point biserial kepada 90 siswa kelas V SDN 2 Penglatan, SDN 1 Alasangker, SDN 2 Alasangker, dan SDN 3 Alasangker.

Hasil analisis uji validitas butir diperoleh 23 butir soal yang dinyatakan valid berdasarkan kriteria $r_{\text {hitung }}>r_{\text {tabel }}$ (taraf siginfikan 5\%). Pengujian reliabilitas internal tes melalui rumus Kuder Richadson (KR20) diperoleh reliabilitas tes kompetensi pengetahuan IPA dari seluruh soal adalah 0,69 dengan derajat reliabilitas tes tergolong tinggi. Hasil uji taraf kesukaran perangkat tes diperoleh nilai 0,44 yang masuk pada kriteria sedang. Hasil perhitungan menunjukkan bahwa 13 butir soal memiliki taraf kesukaran yang tergolong kriteria sukar, 9 butir soal tergolong kriteria sedang, dan 3 butir soal tergolong kriteria mudah. Hasil pengujian daya beda perangkat tes dari 25 butir soal diperoleh 0,28 termasuk ke dalam kriteria cukup baik. Hasil perhitungan menunjukkan terdapat 5 butir soal tergolong kriteria baik, 14 butir soal tergolong kriteria cukup baik, dan 6 butir soal tergolong kriteria kurang baik. Metode analisis data yang digunakan adalah analisis statistik deskriptif dan statistik inferensial dengan uji-t. Statistik deskriptif yang dicari adalah modus, median, mean, standar deviasi, dan varians. Selanjutnya dilakukan uji prasyarat terlebih dahulu sebelum dilakukan uji hipotesis. Uji prasyarat meliputi uji normalitas dan uji homogenitas. Setelah dilakukan uji prasyarat, dilanjutkan menguji hipotesis penelitian menggunakan rumus uji-t polled varians.

\section{Hasil dan pembahasan}

Penelitian pada kelas eksperimen dilaksanakan selama sepuluh kali pertemuan pada tanggal 10 sampai 29 Januari 2020. Pelaksanaan penelitian terlebih dahulu menerapkan tahapan lesson plan selama dua hari mendiskusikan dan merancang perangkat pembelajaran bersama para observer kemudian pada tahap do lesson study dilanjutkan dengan penerapan RPP eksperimen menggunakan sintaks model pembelajaran kooperatif tipe group investigation. Pada tahap akhir penerapan RPP dilanjutkan kegiatan refleksi pada tahap see lesson study. Setelah penerapan RPP dilaksanakan selama tujuh kali pertemuan, kemudian dilanjutkan pada pemberian post-test di hari berikutnya menggunakan instrumen yang telah diujicobakan dan dianalisis.

Deskripsi hasil data dari pelaksanaan penelitian meliputi data hasil post-test kelompok eksperimen dan kelompok pembanding (kontrol). Pemberian perlakuan pada kelompok eksperimen yaitu dibelajarkan model pembelajaran kooperatif tipe group investigation melalui setting lesson study. Pada kelompok pembanding tidak diberi perlakuan, artinya tidak menggunakan model pembelajaran 
kooperatif tipe group investigation melalui setting lesson study. Data kompetensi pengetahuan IPA kelompok eksperimen diperoleh melalui pemberian post-test kepada 27 siswa kelas IV SDN 1 Penglatan. Sedangkan data kompetensi pengetahuan IPA pada kelompok kontrol diperoleh melalui pemberian posttest kepada 23 siswa kelas IV SDN 3 Penglatan. Pada hasil penelitian, untuk memperoleh gambaran terkait kompetensi pengetahuan IPA, data dianalisis melalui statistik deskripstif agar dapat diketahui modus, median, mean, standar deviasi, dan varians. Rangkuman hasil analisis deskriptif disajikan pada Tabel 2 berikut.

Tabel 2 Rekapan Deskripsi Data Hasil Kompetensi Pengetahuan IPA Siswa

\begin{tabular}{ccc}
\hline Statistik Deskripsi & Kelompok Eksperimen & Kelompok Kontrol \\
\hline Modus $(M o)$ & 18 & 13,70 \\
Median $(M d)$ & 17,58 & 14 \\
Mean $(M)$ & 17,43 & 14,27 \\
Standar Deviasi (SD) & 4,02 & 4,05 \\
Varians & 16,16 & 16,40 \\
Skor Maksimum & 23 & 22 \\
Skor Minimum & 10 & 8 \\
Subjek Penelitian $(n)$ & 27 & 23 \\
Rentangan $(R)$ & 16 & 16 \\
Kelas Interval $(k)$ & 6 & 6 \\
Lebar Kelas Interval $(p)$ & 3 & 3 \\
\hline
\end{tabular}

Berdasarkan tabel 2 di atas, untuk kelompok eksperimen diperoleh mean =17,43, median = 17,58, dan modus $=18$, sedangkan untuk kelompok kontrol diperoleh mean $=14,27$, median $=14$, dan modus $=$ 13,70. Hal ini menunjukkan bahwa nilai mean, median, modus kelompok eksperimen lebih besar daripada mean, median, modus kelompok kontrol. Skor maksimal kelas eksperimen $=23$, kelas kontrol $=22$. Skor minimal kelas eksperimen $=10$, kelas kontrol $=8$. Hasil ini menunjukkan sebagian besar skor kompetensi pengetahuan IPA kelompok eksperimen cenderung tinggi.

Pengujian prasyarat yang meliputi uji normalitas dan uji homogenitas dilakukan terlebih dahulu sebelum melakukan uji hipotesis. Pengujian normalitas bertujuan untuk membuktikan frekuensi data hasil penelitian benar-benar berdistribusi normal. Hasil uji normalitas sebaran data diperoleh nilai $\chi^{2}$ hitunghasil post-test kelompok eksperimen sebesar 2,62 dan $\chi^{2}$ hitung hasil post-test kelompok kontrol sebesar 3,38 sedangkan $\chi^{2}$ tabel hasil post-test kelompok eksperimen dan kontrol pada taraf signifikan 5\% yaitu 11,07. Hasil ini menunjukkan $\chi^{2}$ hitunghasil post-test kelompok eksperimen dan kontrol lebih kecil dari $\chi^{2}$ tabel sehingga hasil post-test kelompok eksperimen dan kelompok kontrol berdistribusi normal.

Pada pengujian homogenitas varians menggunakan rumus uji- $F$ dengan kriteria kedua data kompetensi pengetahuan IPA homogen apabila $F_{\text {hitung }}<F_{\text {tabel }}$ (Agung, 2016). Hasil perhitungan uji homogenitas diperoleh nilai $F_{\text {hitung }}=1,02$ lebih kecil dari $F_{\text {tabel }}=4,04$ pada taraf signifikan $5 \%$ dengan $d f_{1}=$ $k-1-2-1=1$ dan $d f_{2}=\mathrm{n}-\mathrm{k}=50-2=48$. Hasil tersebut dapat dinyatakan varians data hasil post-test kelompok eksperimen dan kelompok kontrol adalah homogen. Berdasarkan hasil perhitungan dan analisis uji prasyarat diperoleh bahwa data kompetensi pengetahuan IPA siswa kelompok eksperimen dan kelompok kontrol adalah normal dan homogen sehingga analisis dapat dilanjutkan ketahap pengujian hipotesis penelitian menggunakan statistik uji-t rumus polled varians. Kriteria pengujian $H_{0}$ ditolak dan $H_{1}$ diterima apabila $t_{\text {hitung }}>t_{\text {tabel }}$ pada taraf siginifikan $5 \%$ dengan $d b=n_{1}+n_{2}-2$. Rangkuman hasil perhitungan uji-t polled varians disajikan pada Tabel 3 berikut.

Tabel 3 Rangkuman Hasil Perhitungan Uji-t

\begin{tabular}{ccccccc}
\hline Data & Kelompok & $\mathbf{N}$ & $\bar{x}$ & $\mathbf{s}^{\mathbf{2}}$ & $\boldsymbol{t}_{\text {hitung }}$ & $\boldsymbol{t}_{\text {tabel }}$ \\
\hline Kompetensi & Eksperimen & 27 & 17,43 & 16,16 & \multirow{2}{*}{2,77} & 2,01 \\
Pengetahuan IPA & Kontrol & 23 & 14,27 & 16,40 & & \multirow{2}{*}{. }
\end{tabular}

Keterangan: $\mathrm{N}=$ jumlah; $\bar{x}=$ rata-rata 
Berdasarkan pada tabel hasil perhitungan uji-t di atas, tampak nilai $t_{\text {hitung }}=2,77$ lebih besar dari nilai $t_{\text {tabel }}=2,01$ (taraf signifikan 5\%) sehingga $H_{0}$ ditolak dan $H_{1}$ diterima. Hasil tersebut berarti terdapat perbedaan yang signifikan kompetensi pengetahuan IPA antara kelompok siswa yang dibelajarkan menggunakan model pembelajaran kooperatif tipe group investigation melalui setting lesson study dan kelompok siswa yang dibelajarkan tidak menggunakan model pembelajaran kooperatif tipe group investigation melalui setting lesson study pada siswa SD kelas IV Gugus IV Kecamatan Buleleng Tahun Pelajaran 2019/2020. Hasil pengujian tersebut menunjukkan, jika adanya perbedaan kompetensi pengetahuan IPA antara kelompok eksperimen dengan kelompok kontrol maka model pembelajaran kooperatif tipe group investigation melalui setting lesson study berpengaruh terhadap kompetensi pengetahuan IPA siswa SD kelas IV Gugus IV Kecamatan Buleleng Tahun Pelajaran 2019/2020.

Pertama model kooperatif tipe group Investigation adalah salah satu model kooperatif yang mana proses pembelajarannya menggabungkan antara kerja sama dan proses investigasi dalam menyelesaikan masalah yang diberikan. Menurut Slavin (2005), menyatakan bahwa model group Investigation adalah salah satu bentuk metode yang menekankan pada partisipasi dan aktivitas siswa untuk mencari sendiri pengetahuan tentang materi yang dipelajari sengan sumber belajar yang sudah ada dilingkungan tempat belajarnya. Menurut Suprijono dalam Shoimin, (2014) menyatakan bahwa group Investigation dalam pelaksanannya mengkolaborasikan kerja sama kelompok dengan tahap investegasi yang digunkan untuk menyelesaikan masalah yang mereka pilih sendiri. Dengan adanya kerja sama yang baik antar anak akan membatu proses belajar lebih baik karena mereka saling memberikan apa yang mereka ketahui. Karena mereka saling membantu untuk tercapainya tujuan yang yang ingin dicapai yaitu kesuksesan belajar bersama jadi anak yang mempunyai kemampuan yang berbeda saling melengkapi. Dengan adanya hal ini akan membantu siswa untuk mengembangkan keterampilan sosial dan pengetahuan kognitifnya hal ini sesaui dengan pendapat yang diajukan oleh (Kosasih, 2016) yang menyatakan bahwa kerja kelompok secara tidak langsung mengembangkan demensi kognitif, yaitu dapat mengembangkan kemampuan menerapkan pengetahuan yang dimilikinya. Dengan adanya hal ini akan membantu siswa untuk mengkontruks pengetahuannya sendiri dengan baik. Sehingga pengetahuan yang siswa miliki lebih lama diingatnya. Hal ini senada dengan pendapat Yusuf, (2013) yang menyatakan bahwa kognitif anak akan mempengaruhi daya ingat dan manipulas informasi, sehingga perkembangan kognitif mempengaruhi penguasaan pengetahunnya. Dalam penerapan model ini siswa aktif dalam mengembangkan dan menemukan pengetahuannya sendiri sehingga berdapak terhadap penguasaan pengetahuan yang dimiliki oleh siswa. Hal ini senada dengan hasil penelitian yang dilakukan oleh Octaviani, Diani, \& Romlah, (2018) yang menyatakan bahwa model group investigation sangat membantu proses memahami materi pada pelajaran fisika, sebab siswa belajar aktif dan mengelola proses pembelajaran dari menentukan ide materi serta pemecahan masalah. Pendapat senada juga disampaikan oleh (Taher, Utaya, \& Bachri, 2019) menyatakan bahwa dengan diterapakan model group investigation siswa akan lebih memahami pelajaran geografi yang sedang diberikan karena siswa melakukan investigasi dan bekerja sama dalam kelompok umtuk menyelesaikan masalah yang diberikan yang berakaitan dengan materi. Serta menurut Putra., dkk (2019) dari hasil penelitian dan temunya group investigation mempunyai kelebihan yaitu; 1) Pelajaran berpusat pada siswa sehingga siswa bebas menemukan, menggali dan mencari pemecahan masalah yang diberikan. 2) Sintaks model ini mambantu siswa untuk menguasai konsep tertentu. 3) Mengembangkan kemampuan sosial melalui interkasi, kerjasama dan keterlibatannya dalam pembelajaran.

Kedua Lebih lanjut, pencapaian keberhasilan siswa dalam menguasai kompetensi pengetahuan IPA juga sangat dipengaruhi oleh sintaks model pembelajaran kooperatif tipe group investigation. Setiap sintaks tersebut memiliki keunggulan yang mampu mempengaruhi keaktifan siswa dalam memperoleh pengetahuan dan kebiasaan berkomunikasi secara interaktif. Sintaks model pembelajaran kooperatif tipe group investigation yang dimaksud, yaitu: grouping, planning, investigation, organizing, presenting, dan evaluating. Sintaks tersebut diterapkan pada tahap do (open class) lesson study. Keunggulan dari setiap sintaks tersebut tampak pada tahap grouping dan planning yang mengidentifikasi topik pembelajaran, membentuk siswa ke dalam kelompok yang heterogen, dan proses pembagian tugas kepada masingmasing anggota kelompok. Pembentukan kelompok siswa yang heterogen merupakan langkah awal untuk mendorong keterlibatan siswa aktif dalam belajar. Pemahaman siswa tentang konsep kerjasama terlihat dari interaksi siswa dalam melaksanakan tugas yang telah diberikan sehingga secara tidak langsung siswa sudah mengembangkan dimensi kognitif ranah C3 yaitu mampu menerapkan konsep yang dikuasainya (Kosasih, 2016). Siswa terlatih secara mandiri dalam melaksanakan tugas yang telah di bagi sebelumnya melalui perencanaan tugas dan pemberian keputuan berdasarkan temuan yang diperoleh merupakan capaian siswa dalam mengembangkan dimensi kognitif pada ranah C5. Sintaks yang mencirikan pembelajaran model group investigation, yaitu tahap investigation dan organizing. Siswa secara bebas 
menentukan caranya sendiri dalam memperoleh informasi melalui pengamatan dan percobaan yang dilakukan melalui pengamatan langsung serta mencoba media pembelajaran guna membentuk konsep siswa yang bersifat long-term memory. Pada sintaks organizing siswa mengembangkan kemampuan berpikir kritis melalui berargumen, menanggapi, mengaitkan, dan menyimpulkan berbagai pendapat saat mendiskusikan hasil penyelidikan dengan menjawab LKPD. Menemukan dan mencatat hasil temuan melalui investigasi merupakan salah satu kegiatan mengembangkan dimensi kognitif pada ranah C5 dan C1. Presenting dan evaluating merupakan sintaks terakhir yang terdapat pada model kooperatif tipe group investigation. Siswa memperoleh kesempatan berbagi informasi dan pengetahuan dengan teman di sekitarnya melalui presentasi. Siswa mulai mampu mengkomunikasikan hasil diskusinya di depan kelas dengan penuh rasa tanggung jawab dan percaya diri. Kegiatan presentasi menandakan siswa sudah mampu mengaitkan hasil temuan yang diperoleh dengan pengetahuan konsep-konsep yang ada di dalamnya. Mengacu pada hal tersebut, kegiatan pada tahap presenting mengembangkan dimensi kognitif pada ranah C1 mengingat dan C2 memahami. Peran penting guru pada sintaks evaluating, yaitu untuk meluruskan dan memperbaiki konsep-konsep yang masih keliru disampaikan siswa saat presenting.

Ketiga perbedaan yang signifikan kompetensi pengetahuan IPA siswa yang dibelajarkan menggunakan model pembelajaran kooperatif tipe group investigation melalui setting lesson study disebabkan karena adanya keunggulan dari setiap sintaks model pembelajaran kooperatif tipe group investigation dan tiga tahapan lesson study yang mampu menciptakan kondisi pembelajaran ideal. Adanya kolaborasi antar pendidik (observer) pada tahapan lesson study plan, do, see mampu memberi pengaruh positif bagi kesiapan guru dalam mengajar. Terlebih lagi, penyusunan perangkat pembelajaran pada tahap plan seperti RPP, LKPD, pola tempat duduk siswa, media pembelajaran, dan instrumen penilaian yang disusun terlebih dahulu secara kolaboratif bersama para observer menyebabkan terbentuknya kolegalitas sehingga terbentuk mutual learning (saling belajar). Selain itu, adanya kegiatan open class pada tahap do membuat guru mampu mengetahui setiap perkembangan aktivitas siswa berdasarkan fakta sehingga kompetensi pengetahuan IPA meningkat. Open class yaitu pembelajaran yang berlangsung dengan melibatkan pendidik lain ikut hadir memperhatikan kegiatan pembelajaran yang berlangsung sehingga saat kegiatan evaluasi, guru mengetahui perkembangan belajar siswa dan apa saja yang perlu diperbaiki. Hasil pengamatan observer dijadikan acuan dasar dalam evaluasi pada tahap refleksi. Selanjutnya pada tahap see para observer melaksanakan diskusi terkait pembelajaran yang telah berlangsung kemudian dibahas dan dicarikan solusi. Proses diskusi pada tahap see berlangsung efektif dilihat dari masukanmasukan yang disampaikan. Mengacu pada kegiatan tersebut, segala masukan pada tahap see akan dijadikan acuan untuk merancang ulang pembelajaran di pertemuan berikutnya dan pembuatan perangkat lain untuk menunjang pembelajaran baru. Menurut (Vlorensius, Nugroho, \& Andari, 2016) Lesson study memberikan kesempatan kepada guru untuk melakukan, merencanakan dan mengembangkan perangkat pembelajaran serta melakukan perbaikan terhadap pelaksanaan sesaui dengan masukan dari observer. Penerapan model pembelajaran kooperatif tipe group investigation melalui setting lesson study secara kolaboratif memberi manfaat yang dapat dirasakan bersama melalui terjalinnya kerjasama yang baik antara guru dengan guru, guru dengan siswa, dan siswa dengan siswa. Peran guru dalam hal ini adalah sebagai fasilitator sedangkan siswa berperan sebagai subjek belajar yang membutuhkan kerjasama yang baik agar tujuan pembelajaran dapat tercapai. Siswa aktif belajar dan guru memberikan bimbingan dari materi yang sedang dipelajari siswa. Berdasarkan temuan yang ada dalam penelitian ini, dapat dinyatakan bahwa kelompok siswa yang dibelajarkan menggunakan model pembelajaran kooperatif tipe group investigation melalui setting lesson study lebih berpengaruh positif terhadap kompetensi pengetahuan IPA siswa, dibandingkan kelompok siswa yang tidak dibelajarkan menggunakan model pembelajaran kooperatif tipe group investigation melalui setting lesson study.

Penemuan ini juga didukung dengan penelitian yang dilakukan oleh Putra., dkk (2019) menyatakan bahwa dengan terdapat perbedaan penguasaan konsep IPA antara kelompok siswa yang dibelajarkan model pembelajaran kooperatif tipe group investigation berbasis lesson study dan kelompok siswa yang dibelajarkan pembelajaran konvensional pada siswa kelas IV semester II di SD Gugus XIV Kecamatan Buleleng tahun pelajaran 2017/2018. Pendapat (Harta, Dharsana, \& Renda, 2019) menyatakan bahwa terdapat perbedaan yang signifikan hasil belajar IPA antara siswa yang dibelajarkan dengan model pembelajaran kooperatif tipe TSTS melalui Lesson Study dan siswa yang tidak belajar dengan model pembelajaran kooperatif tipe TSTS melalui lesson study pada siswa kelas V Semester Genap Di SD Negeri 2 Anturan Kecamatan Buleleng Tahun Pelajaran 2017/2018. Hal tersebut diperoleh dari Hasil uji-t menunjukkan bahwa thitung adalah 2,17 , sedangkan ttabel pada taraf signifikansi $5 \%$ dan $\mathrm{db}=55$ adalah 2,021. Di samping itu, rata-rata skor hasil belajar IPA siswa yang belajar dengan model pembelajaran kooperatif tipe TSTS melalui lesson study $(24,03)$ lebih tinggi dari pada rata-rata skor siswa yang tidak belajar dengan model pembelajaran kooperatif tipe TSTS melalui lesson study $(20,08)$. Serta menurut Wiyasa, (2017) terdapat perbedaan yang signifikan antara hasil belajar pendidikan jasmani mahasiswa 
yang dibelajarkan dengan menggunakan model pembelajaran tipe NHT dalam setting lesson study dengan mahasiswa yang dibelajarkan secara konvensional.

Berdasarkan jabaran sebelumnya terdapat pengaruh yang signifikan dengan menggunakan model koperatif tipe group investigation seting lesson study terhadp kompetensi pengetahuan IPA siswa. Dengan adanya kombinasi kedau model tersebut akan membuat proses pembelajaran lebih aktif, berpusat pada siswa serta dengan adanya model tersebut siswa akan lebih mengembangkan kemampuan sosialnya, yang secara tidak langsung akan mempengaruhi kompetensi pengetahuan IPA.

\section{Simpulan dan saran}

Berdasarkan hasil pengujian hipotesis dan pembahasan, dapat disimpulkan bahwa terdapat perbedaan yang signifikan kompetensi pengetahuan IPA antara kelompok siswa yang dibelajarkan menggunakan model pembelajaran kooperatif tipe group investigation melalui setting lesson study dan kelompok siswa yang dibelajarkan tidak menggunakan model pembelajaran kooperatif tipe group investigation melalui setting lesson study pada siswa kelas IV SD di Gugus IV Kecamatan Buleleng Tahun Pelajaran 2019/2020. Nilai rata-rata kompetensi pengetahuan IPA siswa kelompok eksperimen yaitu 17,43 lebih besar dari nilai rata-rata kelompok kontrol yaitu 14,27. Hasil pengujian hipotesis juga menunjukkan nilai $t_{\text {hitung }}=2,77$ lebih besar dari nilai $t_{\text {tabel }}=2,01$ pada taraf signifikan $5 \%$ dengan $d b=n_{1}+$ $n_{2}-2=27+23-2=48$ sehingga $H_{1}$ diterima dan $H_{0}$ ditolak. Berlandaskan pada hasil perhitungan dan analisis data dapat dipahami bahwa, jika terdapat perbedaan yang signifikan kompetensi pengetahuan IPA siswa antara kelompok eksperimen dengan kelompok kontrol maka model pembelajaran kooperatif tipe group investigation melalui setting lesson study berpengaruh terhadap kompetensi pengetahuan IPA siswa kelas IV SD Gugus IV Kecamatan Buleleng Tahun Pelajaran 2019/2020.

Saran disampaikan berdasarkan penelitian yang telah dilakukan yaitu: (1) kepada siswa diharapkan untuk belajar memahami, bukan lagi menghafal karena hal tersebut sangat dibutuhkan untuk menyelesaikan masalah dalam kehidupan sehari-hari. (2) Kepada guru diharapkan menggunakan model pembelajaran kooperatif tipe group investigation melalui setting lesson study dalam meningkatkan kemampuan profesional guru mengelola pembelajaran IPA siswa. (3) Kepada kepala sekolah diharapkan untuk lebih memfasilitasi guru dalam penggunaan model pembelajaran kooperatif tipe group investigation melalui setting lesson study. (4) Kepada peneliti lain diharapkan melaksanakan penelitian lebih lanjut terkait pembelajaran yang menggunakan model kooperatif tipe group investigation melalui setting lesson study pada bidang ilmu yang lainnya dengan tetap memperhatikan karakteristik siswa.

\section{Daftar Rujukan}

Abizar, H. (2017). Buku Master Lesson Study. Yogyakarta: DIVA Press.

Agung, A. A. A. G. (2016). Statistika Inferensial. Singaraja: Fakultas Ilmu Pendidikan.

Budiastra, I. K., Sudana, D. N., \& Arcana, N. (2015). Pengaruh Model Kooperatif Tipe GI (Group Investigation) Terhadap Keterampilan Berpikir Kritis Dalam Pembelajaran IPA. E-Journal PGSD Universitas Pendidikan Ganesha, 31.

Candiasa, I. M. (2011). Pengujian Instrumen Penelitian Disetrai Aplikasi Iteman dan Bigsteps. Singaraja: Undiksha Press.

Harta, J., Dharsana, I. K., \& Renda, N. T. (2019). Pengaruh Model Tsts Melalui Lesson Study Terhadap Hasil Belajar IPA. Jurnal Mimbar Ilmu, 24(1), 95-104. https://doi.org/10.23887/mi.v24i1.17458

Hayati, D. K. (2017). Pengembangan Buku Ajar Konsep Dasar IPA Untuk Meningkatkan Keterampilan Proses Sains Mahasiswa. Jurnal Gentala Pendidikan Dasar, 2(1), 151-167. https://doi.org/10.22437/gentala.v2i1.6824

Jampel, I. N. (2017). Pelatihan Pengembangan Asesmen Autentik Dalam Implementasi Kurikulum 2013 Di Sekolah Dasar Berbasis Lesson Study Bagi Guru-Guru Sd Di Kecamatan Buleleng. Jurnal Widya Laksana, 5(1), 10. https://doi.org/10.23887/jwl.v5i1.9095 
Kemendikbud. Lampiran Permendikbud Nomor 37 Tahun 2018 Tentang Kompetensi Inti dan Kompetensi Dasar Pelajaran pada Kurikulum 2013 pada Pendidikan Dasar dan Pendidikan Menengah. , (2018).

Kosasih. (2016). Strategi Belajar dan Pembelajaran Implementasi Kurikulum 2013. Bandung: Yrama Widya. Koyan, I. W. (2011). No Asesmen dalam Pendidikan. Singaraja: Universitas Pendidikan Ganesha Press.

Kurniasih, Iman, \& Seni, B. (2016). Ragam Pengembangan Model Pembelajaran untuk Meningkatkan Profesionalitas Guru.

Octaviani, E., Diani, R., \& Romlah. (2018). Pengaruh Group Investigation Terhadap Hasil Belajar Fisika Peserta Didik Pada Pokok Bahasan Gerak Lurus Kelas X di SMAN 1 Jabung Lampung Timur. Indonesian Journal of Science and Mathematics Education, 01(2), 23-28.

Pindo, H., \& Rinci, S. (2018). Meningkatkan Hasil Belajar Siswa dengan Alat Peraga pada Mata Pelajaran IPA Kelas IV SDN Nomor 14 Simbolon Purba. School Education Journal, 8(2), 121-129.

Putra, Margunayasa, I. G., \& Wibawa, I. M. C. (2019). Pengaruh Model Pembelajaran Group Investigation (GI) Berbasis Lesson Study Terhadap Penguasaan Konsep IPA. Jurnal Pedagogi Dan Pembelajaran, $1(2), 84-93$.

Samatowa, U. (2016). Pembelajaran IPA di Sekolah Dasar. Jakarta: PT Indeks.

Santyasa, I. W. (2017). Pembelajaran Inovatif. Singaraja: Undiversitas Pendidikan Ganesha.

Shoimin, A. (2014). 68 Model Pembelajaran Inovatif dalam Kurikulum 2013. Yogyakarta: AR-Ruzz Media. Slavin, R. E. (2005). Cooperative Laerning. London: Allymand Bacon.

Taher, A., Utaya, S., \& Bachri, S. (2019). Pengaruh Model Pembelajaran Kooperatif Tipe 1059 Group Investigation terhadap Hasil Belajar Geografi. Jurnal Serunai Matematika, 4(4), 456-461. https://doi.org/10.37755/jsm.v11i1.110

Tristiantari, N. K. D., \& Sumantri, I. M. (2016). Model Pembelajaran Cooperatif Integrated Reading Composition Berpola Lesson Study Meningkatkan Keterampilan Membaca Dan Menulis. JPI (Jurnal Pendidikan Indonesia), 5(2), 203. https://doi.org/10.23887/jpi-undiksha.v5i2.8493

Tursinawati, T., \& Widodo, A. (2019). Pemahaman Nature of Science (NoS) Di Era Digital: Perspektif Dari Mahasiswa PGSD. Jurnal IPA \& Pembelajaran IPA, 3(1), 1-9. https://doi.org/10.24815/jipi.v3i1.13294

Vlorensius, Nugroho, E. D., \& Andari, K. D. W. (2016). Persepsi dan Preferensi Guru-guru di Kabupaten Tana Tidung Terhadap Penerapan Lesson Study Berdasarkan Motivasi Dan Sikap Untuk Pengembangan Profesionalisme Guru Wilayah Perbatasan. 2(3), 277-291.

Widiartini, P. D. O., Putra, M., \& Manuaba, I. B. S. (2019). Pengaruh Model Pembelajaran Group Investigation Berbasis Budaya Penyelidikan Terhadap Kompetensi Pengetahuan Ipa Kelas Iv. Jurnal Pendidikan Multikultural Indonesia, 1(1), 8. https://doi.org/10.23887/jpmu.v1i1.20762

Wiyasa, I. K. N. (2017). Pengaruh model pembelajaran kooperatif tipe NHT dalam setting lesson study terhadap hasil belajar pendidikan jasmani. Jurnal Pendidikan Jasmani Indonesia, 13(2), 72-78. https://doi.org/10.21831/jpji.v13i2.21069

Yusuf, L. . (2013). Mata Kuliah Dasar Profesi (MKDP) Bagi Para Mahasiswa Calon Guru di Lembaga Pendidikan Tenaga Kependidikan (LPTK). Jakarta: Rajawali Pres. 